\title{
Ten-year trends of atmospheric mercury in the high Arctic compared to Canadian sub-Arctic and mid-latitude sites
}

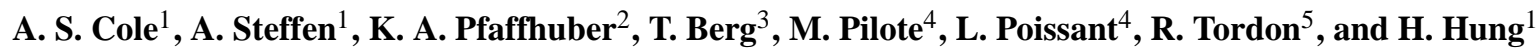 \\ ${ }^{1}$ Air Quality Research Division, Science and Technology Branch, Environment Canada, 4905 Dufferin St., Toronto, ON, \\ Canada \\ ${ }^{2}$ Norwegian Institute for Air Research, Instituttveien 20, 2027 Kjeller, Norway \\ ${ }^{3}$ Dept. of Chemistry, Norwegian University of Science and Technology, Trondheim, Norway \\ ${ }^{4}$ Aquatic Contaminants Research Division, Science and Technology Branch, Environment Canada, 105 McGill Street, 7th \\ floor, Montréal, QC, Canada \\ ${ }^{5}$ Meteorological Service of Canada, Environment Canada, 45 Alderney Drive, 16th floor, Dartmouth, NS, Canada
}

Correspondence to: A. Steffen (alexandra.steffen@ec.gc.ca)

Received: 13 June 2012 - Published in Atmos. Chem. Phys. Discuss.: 13 August 2012

Revised: 30 January 2013 - Accepted: 31 January 2013 - Published: 7 February 2013

\begin{abstract}
Global emissions of mercury continue to change at the same time as the Arctic is experiencing ongoing climatic changes. Continuous monitoring of atmospheric mercury provides important information about long-term trends in the balance between transport, chemistry, and deposition of this pollutant in the Arctic atmosphere. Ten-year records of total gaseous mercury (TGM) from 2000 to 2009 were analyzed from two high Arctic sites at Alert (Nunavut, Canada) and Zeppelin Station (Svalbard, Norway); one sub-Arctic site at Kuujjuarapik (Nunavik, Québec, Canada); and three temperate Canadian sites at St. Anicet (Québec), Kejimkujik (Nova Scotia) and Egbert (Ontario). Five of the six sites examined showed a decreasing trend over this time period. Overall trend estimates at high latitude sites were: $-0.9 \% \mathrm{yr}^{-1}(95 \%$ confidence limits: $-1.4,0)$ at Alert and no trend $(-0.5,+0.7)$ at Zeppelin Station. Faster decreases were observed at the remainder of the sites: $-2.1 \% \mathrm{yr}^{-1}(-3.1,-1.1)$ at Kuujjuarapik, $-1.9 \% \mathrm{yr}^{-1}(-2.1,-1.8)$ at St. Anicet, $-1.6 \% \mathrm{yr}^{-1}$ $(-2.4,-1.0)$ at Kejimkujik and $-2.2 \% \mathrm{yr}^{-1}(-2.8,-1.7)$ at Egbert. Trends at the sub-Arctic and mid-latitude sites agree with reported decreases in background TGM concentration since 1996 at Mace Head, Ireland, and Cape Point, South Africa, but conflict with estimates showing an increase in global anthropogenic emissions over a similar period. Trends in TGM at the two high Arctic sites were not only less negative (or neutral) overall but much more variable by season. Possible reasons for differences in seasonal and overall
\end{abstract}

trends at the Arctic sites compared to those at lower latitudes are discussed, as well as implications for the Arctic mercury cycle. The first calculations of multi-year trends in reactive gaseous mercury (RGM) and total particulate mercury (TPM) at Alert were also performed, indicating increases from 2002 to 2009 in both RGM and TPM in the spring when concentrations are highest.

\section{Introduction}

Mercury in the atmosphere is transported from natural and anthropogenic emission sources to all parts of the globe. Most of this mercury is in the form of gaseous elemental mercury (GEM) due to its estimated 6-24 month lifetime in the atmosphere. Shorter-lived reactive gaseous mercury (RGM) and total particulate mercury (TPM) in the atmosphere can either be emitted directly or created by oxidation of GEM and deposit within hours to weeks (Schroeder and Munthe, 1998). Following deposition, inorganic forms of mercury can be re-emitted or remain in soil, vegetation, and surface water. A fraction of the inorganic mercury can be methylated by microbial activity in wetlands and sediments as well as in fresh and salt water; toxic methylmercury can then enter the food web, where it bioaccumulates and biomagnifies and poses a health risk to humans and/or wildlife (see Selin, 2009 for review). 
In the Arctic, high levels of mercury have been observed in people and wildlife (AMAP, 2005), with historical mercury records indicating a significant anthropogenic source (Dietz et al., 2009; Muir et al., 2009). There are very few local sources of mercury in the Arctic and thus anthropogenic mercury must originate elsewhere. Since the atmosphere is a significant source of mercury to the region (Outridge et al., 2008), long-term monitoring of atmospheric mercury in the Arctic is crucial for assessing the sensitivity of the atmospheric input to changes in global mercury emissions, atmospheric circulation, and deposition (wet and dry). In addition, mercury in the Arctic undergoes large-scale rapid conversion of GEM to RGM and TPM in the springtime in so-called atmospheric mercury depletion events (AMDEs) (Schroeder et al., 1998; Berg et al., 2003; Steffen et al., 2008). These chemical reactions are associated with sea ice and/or snow pack chemistry through surface bromine reactions (Lindberg et al., 2002; Simpson et al., 2007). Therefore, changes in the cryosphere may also impact mercury deposition in the Arctic through atmospheric chemistry and ocean-air exchange, adding to the impetus for ongoing monitoring in this region (AMAP, 2011).

Recently, GEM concentrations at Alert, in the Canadian high Arctic, were shown to have decreased over 1995-2007 at a rate of $0.6 \% \mathrm{yr}^{-1}$ (range $\left.0.1-0.9 \% \mathrm{yr}^{-1}\right)$ (Cole and Steffen, 2010). This was followed by reports of steeper declines of roughly $2.7 \% \mathrm{yr}^{-1}$ in total gaseous mercury (TGM, the sum of GEM and RGM) measured at Cape Point, South Africa, from 1996 to 2009 (Slemr et al., 2011) and 1.6$2.0 \% \mathrm{yr}^{-1}$ in TGM measured in background air masses at Mace Head, Ireland, over the same period (Ebinghaus et al., 2011). These are the only locations that have reported at least $10 \mathrm{yr}$ of continuous TGM data, highlighting the need for more widely spread monitoring (Sprovieri et al., 2010). Nevertheless, these results from geographically diverse locations suggest a decline in global mercury levels in recent years following relatively stable concentrations in the late 1990s (Slemr et al., 2003). This is not consistent with recent emission estimates of constant or increasing anthropogenic mercury emissions over much of this period (Pacyna et al., 2006; AMAP/UNEP, 2008; Pirrone et al., 2010; Streets et al., 2011). In addition, the difference in trends between Alert and Mace Head is somewhat unexpected. It is reasonable to expect an interhemispheric gradient in TGM concentrations and their trends (i.e. between Cape Point and Mace Head/Alert), given that the tropospheric lifetime of mercury is approximately equal to the lifetime for mixing Northern and Southern Hemispheric air (Holmes et al., 2010). However, the trend analysis at Mace Head was limited to air masses from background areas (North Atlantic, Arctic Ocean, Greenland) and Alert is far from local sources, so both sites should be dominated by the Northern Hemispheric background concentration of mercury and reflect trends in that background, to a first approximation.
To extend the comparison between Arctic and mid-latitude trends to more than two sites, here we apply a consistent trend analysis to ten years of TGM data from two Arctic sites, one sub-Arctic site, and three Canadian mid-latitude sites. In addition, we investigate the role of AMDEs in this trend by (a) examining the trend on a monthly basis; (b) including a sub-Arctic site that experiences AMDEs; and (c) assessing for the first time eight-year time trends and variability in RGM and TPM at Alert.

\section{Methods}

Total gaseous mercury (TGM) has been continuously monitored at Alert since 1995, Zeppelin Station since 2000, Kuujjuarapik since late 1999, Egbert and Kejimkujik since 1996, and St. Anicet since 1994. Site locations are shown in Fig. 1 and described briefly in Table 1 . Alert is located on the northern tip of Ellesmere Island on the shore of the Lincoln Sea, on a plateau approximately $6 \mathrm{~km}$ from the ocean (Cole and Steffen, 2010). Zeppelin Station is located on a ridge of Zeppelin Mountain accessed by cable car from the coastal settlement of Ny-Alesund, on the western coast of the island of Spitsbergen (Berg et al., 2003). Kuujjuarapik is in a sub-Arctic tundra region on the eastern shore of Hudson Bay (Poissant and Pilote, 2003). The three mid-latitude sites across eastern Canada are all rural sites affected to varying degrees by regional pollution sources, as described in detail elsewhere (Poissant, 1997; Kellerhals et al., 2003).

TGM measurements were made using Tekran 2537A instruments. The instruments sample ambient air at 3-6 m above ground level through a $0.2 \mu \mathrm{m}$ Teflon filter $(47 \mathrm{~mm}$ diameter) at the outside inlet followed by an approximately 10 $15 \mathrm{~m}$ heated sample line and a second Teflon filter at the inlet to the instrument. At St. Anicet, the inlet differs in that the Teflon filter inlet is coupled to a sampling manifold (Pyrex). As well, the inlet at Zeppelin includes a soda lime trap placed in line before the instrument filter (Aspmo et al., 2005). In the instrument, ambient air is pulled through one of two gold collectors for 5-30 min, providing continuous concentration measurements. Mercury is adsorbed onto the gold trap for a period of time at a specified flow rate. Once the sampling is complete, the trap is then analysed while the second trap collects the next sample. The gold trap is heated to approximately $500^{\circ} \mathrm{C}$ and the mercury is thermally desorbed into an argon stream and detected using cold vapour atomic fluorescence spectrometry. This method has been described in detail in Steffen et al. (2008) (and references therein). Results from a previous campaign at Alert (Steffen et al., 2002) as well as laboratory tests (Swartzendruber et al., 2008) suggest that the two inlet filters remove some or all of the reactive gaseous mercury (RGM) so that the measured concentrations represent gaseous elemental mercury. However, other field tests suggest that RGM does pass through the filters and is included in the measured TGM concentration 
Table 1. Site details.

\begin{tabular}{lllll}
\hline Site & Latitude & Longitude & Elevation, m & Site description \\
\hline Alert & $82.5^{\circ} \mathrm{N}$ & $62.3^{\circ} \mathrm{W}$ & 210 & Remote Arctic; tundra \\
Zeppelin Stn & $78.9^{\circ} \mathrm{N}$ & $11.9^{\circ} \mathrm{E}$ & 474 & Remote Arctic mountain ridge; tundra \\
Kuujjuarapik & $55.3^{\circ} \mathrm{N}$ & $77.7^{\circ} \mathrm{W}$ & 14.3 & Forest/tundra; sub-Arctic \\
St. Anicet & $45.1^{\circ} \mathrm{N}$ & $74.3^{\circ} \mathrm{W}$ & 49 & Flat, grassy, rural; urban/industrial within $100 \mathrm{~km}$ \\
Kejimkujik & $44.4^{\circ} \mathrm{N}$ & $65.2^{\circ} \mathrm{W}$ & 127 & Forested rural/remote \\
Egbert & $44.2^{\circ} \mathrm{N}$ & $79.8^{\circ} \mathrm{W}$ & 251 & Forest/agricultural; urban within $100 \mathrm{~km}$ \\
\hline
\end{tabular}

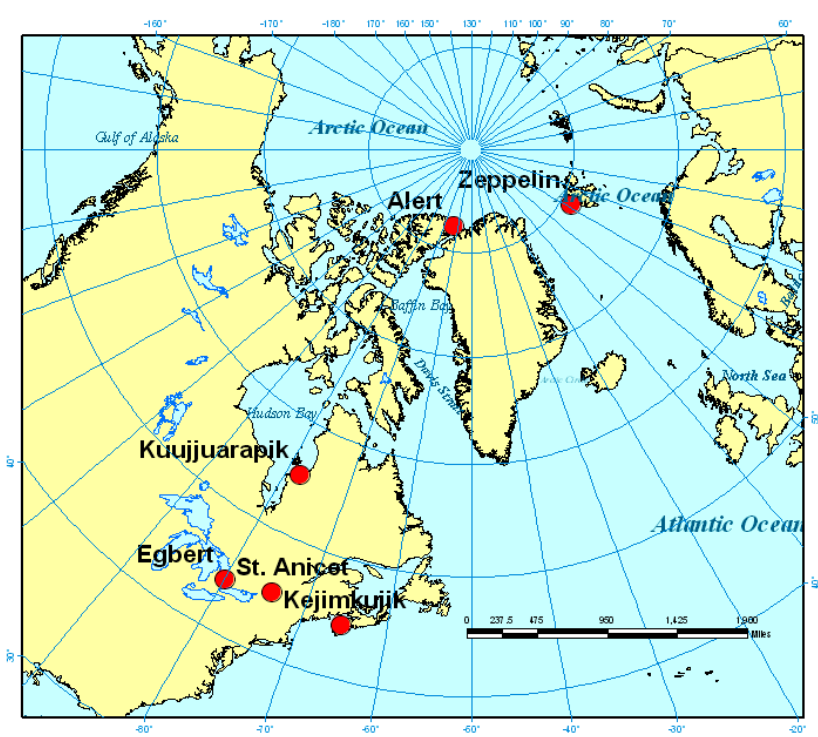

Fig. 1. Site map.

(Temme et al., 2003; Slemr et al., 2009), perhaps depending on field conditions. In addition, the soda lime trap at Zeppelin likely removes RGM (Aspmo et al., 2005). In this paper we use the terminology TGM to represent mercury measured by the 2537A instrument, with the caveat that some RGM may be lost and this number therefore represents a lower limit of TGM. However, RGM comprises only a few percent of TGM in most cases and instrumental setup at each site was consistent over the time period studied. For the Canadian sites, consistent TGM sampling protocols were followed during the measurement period (Steffen and Schroeder, 1999) and the data were treated by an objective quality control (QC) process, the Environment Canada-developed Research Data Management and Quality Assurance System (RDMQ) (McMillan et al., 2000). Specifics of the QC criteria for the Canadian Atmospheric Mercury Measurements Network (CAMNet) are discussed in depth elsewhere (Steffen et al., 2012). At Zeppelin, protocols for the Norwegian mercury monitoring program were applied, many of which are similar to the Canadian protocols. The data from Zeppelin have been quality controlled by hand using many of the same QC criteria as the RDMQ system. The intersite precision of the
TGM measurements for the CAMNet sites following earlier audits (Tait et al., 2000) was determined to be $9 \%$ (Temme et al., 2007); this is a conservative estimate for a single site (where precision may be as good as $2 \%$, Poissant, 2000) that takes into account instrument and operator changes over the years.

Speciated Hg (GEM, RGM and TPM) has been measured at Alert since 2002 using a Tekran Mercury 1130, 1135 and 2537 speciation unit, as described in the literature (Landis et al., 2002; Steffen et al., 2008). Briefly, air is pulled into the analyzer through a Teflon coated elutriator and impactor designed to remove particles $>2.5 \mu \mathrm{m}$ at flow rates of $10.0 \mathrm{~L} \mathrm{~min}^{-1}$ (particle size cut off varies with flow rate). The sample air flows through a KCl-coated quartz denuder to trap the RGM in the 1130 unit and then passes through a quartz particulate filter to trap the remainder of the particles in the 1135 unit. GEM passes through both the 1130 and 1135 units during sampling mode and is carried into the 2537 analyzer for analysis. Due to their very low concentration, RGM and TPM are accumulated for 1 to $3 \mathrm{~h}$ while the GEM is simultaneously collected and measured every $5 \mathrm{~min}$ by the 2537 downstream. After the collection period, RGM and TPM are sequentially thermally desorbed, pyrolyzed to GEM in zero air and analyzed by the 2537 unit. All species are measured as GEM, thus the 2537 instrument is internally and externally calibrated as described for the TGM measurements. Exact chemical identification of RGM and TPM fractions are still not known and thus are operationally defined as inorganic gaseous $\mathrm{Hg}$ that adsorbs to $\mathrm{KCl}$ and $\mathrm{Hg}$ associated with $\mathrm{PM}_{2.5}$, respectively. Early tests on the 1130 denuder system estimated an RGM precision of about $15 \%$ (Landis et al., 2002), though comparisons between different methods have revealed differences for RGM and TPM measurements on the order of 30-80\% (Ebinghaus et al., 1999; Munthe et al., 2001; Aspmo et al., 2005). Using a consistent instrument configuration at a single site, with rigorous and consistent protocols for sample collection and data treatment (Steffen et al., 2012), we estimate a precision of 15-30\% for RGM and TPM measurements. Based on the intercomparison results cited, absolute concentrations would be less reliable than the time trends discussed here. The method detection limit for RGM and TPM was calculated as 3 times the standard deviation of the two zero air blanks measured after the TPM and 
Table 2. Median, mean, and trends in TGM for 2000-2009, with $95 \%$ confidence range on trends.

\begin{tabular}{lccrr}
\hline Site & $\begin{array}{c}\text { Median TGM for } \\
\text { 2000-2009, } \mathrm{n} \mathrm{m}^{-3}\end{array}$ & $\begin{array}{c}\text { Mean TGM } \pm \text { standard } \\
\text { deviation, } \mathrm{ng} \mathrm{m}^{-3}\end{array}$ & $\begin{array}{r}\text { TGM trend, } \\
\mathrm{pg} \mathrm{m}^{-3} \mathrm{yr}^{-1}\end{array}$ & $\begin{array}{r}\text { TGM trend, } \\
\% \mathrm{yr}^{-1}\end{array}$ \\
\hline Alert & 1.53 & $1.50 \pm 0.35$ & $-13(-21,0)$ & $-0.9(-1.4,0)$ \\
Zeppelin Stn & 1.60 & $1.57 \pm 0.24$ & $+2(-7,+12)$ & $+0.1(-0.5,+0.7)$ \\
Kuujjuarapik & 1.62 & $1.66 \pm 0.44$ & $-33(-50,-18)$ & $-2.1(-3.1,-1.1)$ \\
St. Anicet & 1.52 & $1.55 \pm 0.26$ & $-29(-31,-27)$ & $-1.9(-2.1,-1.8)$ \\
Kejimkujik & 1.37 & $1.38 \pm 0.33$ & $-23(-33,-13)$ & $-1.6(-2.4,-1.0)$ \\
Egbert & 1.58 & $1.58 \pm 0.30$ & $-35(-44,-27)$ & $-2.2(-2.8,-1.7)$ \\
\hline
\end{tabular}

RGM measurement cycles and was found to be $3.0 \mathrm{pg} \mathrm{m}^{-3}$ over the eight years of measurements.

The seasonal trend analysis used daily averaged TGM values ( $25 \%$ data completeness required within each day) from 2000 to 2009, inclusive. This time period was chosen as the maximum range for which all six sites had data coverage. Trends in each month were calculated using the seasonal Kendall test for trend and the related Sen's slope calculation (Gilbert, 1987). This method is an extension of the nonparametric Mann-Kendall test for trend, which is a recommended trend test when there are missing values and where the data are not normally distributed - both of which apply to these data sets. In the seasonal Kendall method, data from the 12 months are treated as 12 separate data sets. For each month, the presence of a trend is confirmed or rejected by the Mann-Kendall test and a slope is estimated using Sen's nonparametric estimator of slope. For the purposes of these calculations, each daily average in the month is treated as a replicate measurement. An overall annual trend can be estimated from the monthly trend statistics; however, this estimate is less reliable if the monthly trends are not sufficiently homogeneous. A test for seasonal homogeneity was therefore performed as well (van Belle and Hughes, 1984). If seasonal trends were homogeneous, the results were used to determine an overall trend for the entire period. Otherwise, homogeneous seasonal trends and overall trends were calculated using monthly median TGM ( $75 \%$ data coverage required within each month). The disadvantage of this technique is that it produces a linear trend over the entire period and can miss complex patterns such as a decrease followed by an increase.

Trends in speciated mercury (GEM, RGM and TPM) over the 8-yr period 2002-2009 were also calculated using the same method, again applied to daily averages. In certain months, concentrations of RGM and TPM were below the method detection limit $\left(3.0 \mathrm{pg} \mathrm{m}^{-3}\right)$ for more than half of the data points over the $8 \mathrm{yr}$. Therefore, trends in those months were discarded and no overall trend for the entire data set was calculated. Monthly trends were also discarded if there were fewer than five years with at least $75 \%$ data coverage in that month.

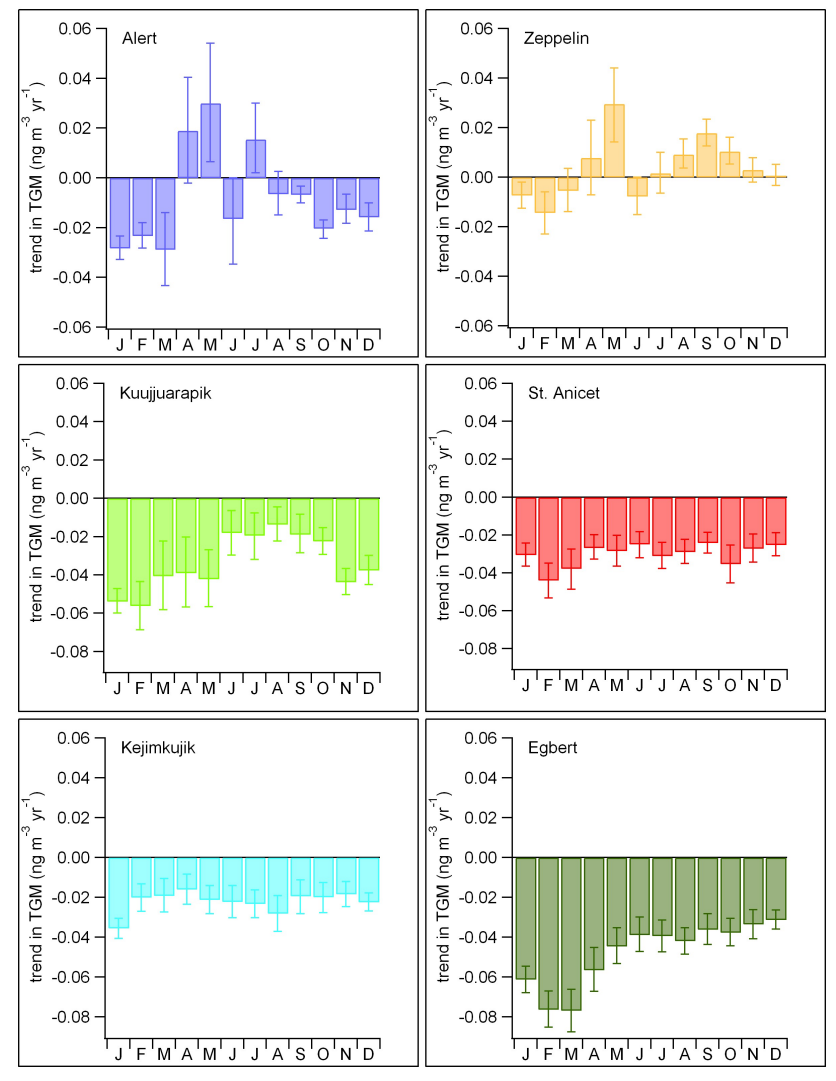

Fig. 2. Seasonal (monthly) trends in TGM based on daily average measurements 2000-2009. Error bars represent $95 \%$ confidence limits.

\section{Results and discussion}

Monthly trends in TGM based on daily average concentrations are shown in Fig. 2 for all six sites. Each bar represents the median rate of increase (positive) or decrease (negative) over the ten years using data from a single month. At all sites other than St. Anicet, these trend values were significantly different from month to month (i.e. the trend was found to be seasonally heterogeneous) and therefore the calculation was repeated using monthly median values at those sites (not shown). In all cases, the monthly trends calculated 


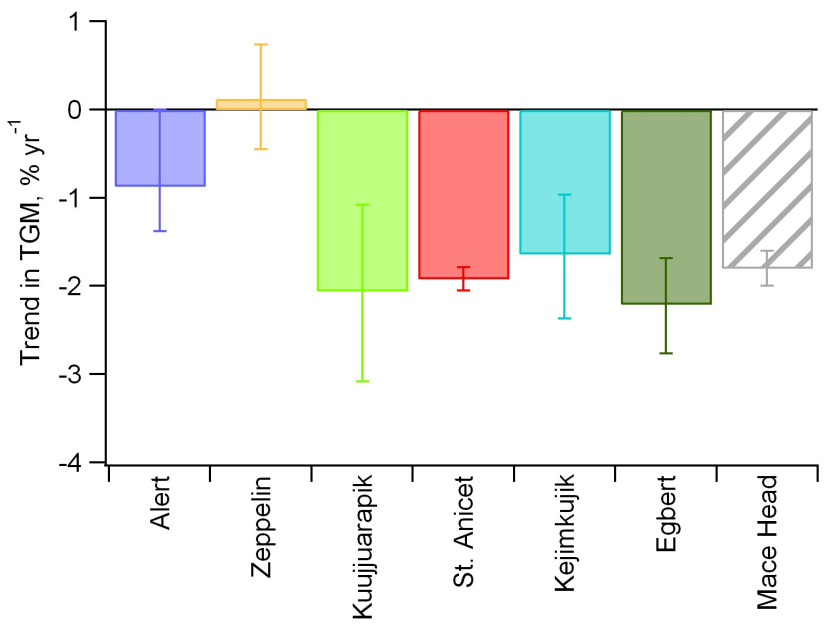

Fig. 3. Trends in TGM at all sites for 2000-2009 and Mace Head, Ireland for 1996-2009. Error bars represent $95 \%$ confidence limits.

using median values were within the uncertainty of the trends calculated using daily averages, but the error bars were larger such that the trends were not seasonally heterogeneous.

Overall trends based on all months, expressed as a percent of the median TGM concentration for the entire data set, are compared in Fig. 3 and Table 2. Table 2 also compares summary statistics and absolute TGM trends for each site. Figure 3 also includes the reported trend in baseline air masses arriving at Mace Head, Ireland, for 1996-2009 (Ebinghaus et al., 2011). The trend from Cape Point, South Africa (Slemr et al., 2011) is not directly compared here since both the measurement technique (prior to 2007) and the trend calculation method differ from those used for the sites shown. At St. Anicet, monthly trends based on daily averages were homogeneous and therefore an overall trend could be determined with better precision than at the other sites where monthly medians were used to calculate the overall trend.

It is clear from Fig. 3 that the overall trend at Alert was significantly less negative than the trends at Egbert, St. Anicet and Mace Head. While the overall trend at Alert was not significantly different from those at Kuujjuarapik and Kejimkujik (at $95 \%$ confidence), there were no months in which the trend at Alert was significantly more negative than the trends at Kuujjuarapik or Kejimkujik (Fig. 2), suggesting that the overall trend at Alert is most likely less negative than the overall trend at those two sites as well. The TGM trend at Zeppelin Station was significantly higher than at all other sites except Alert. Trends at non-Arctic sites agreed well with the reported decrease in background TGM concentration at Mace Head, Ireland of $(-1.8 \pm 0.2) \% \mathrm{yr}^{-1}$, though the time period used for Mace Head was longer. TGM trends at Alert, St. Anicet, Egbert, and Kejimkujik were all more negative than earlier reported trends to the end of 2004 or 2005 (Temme et al., 2007), supporting evidence of an accel-

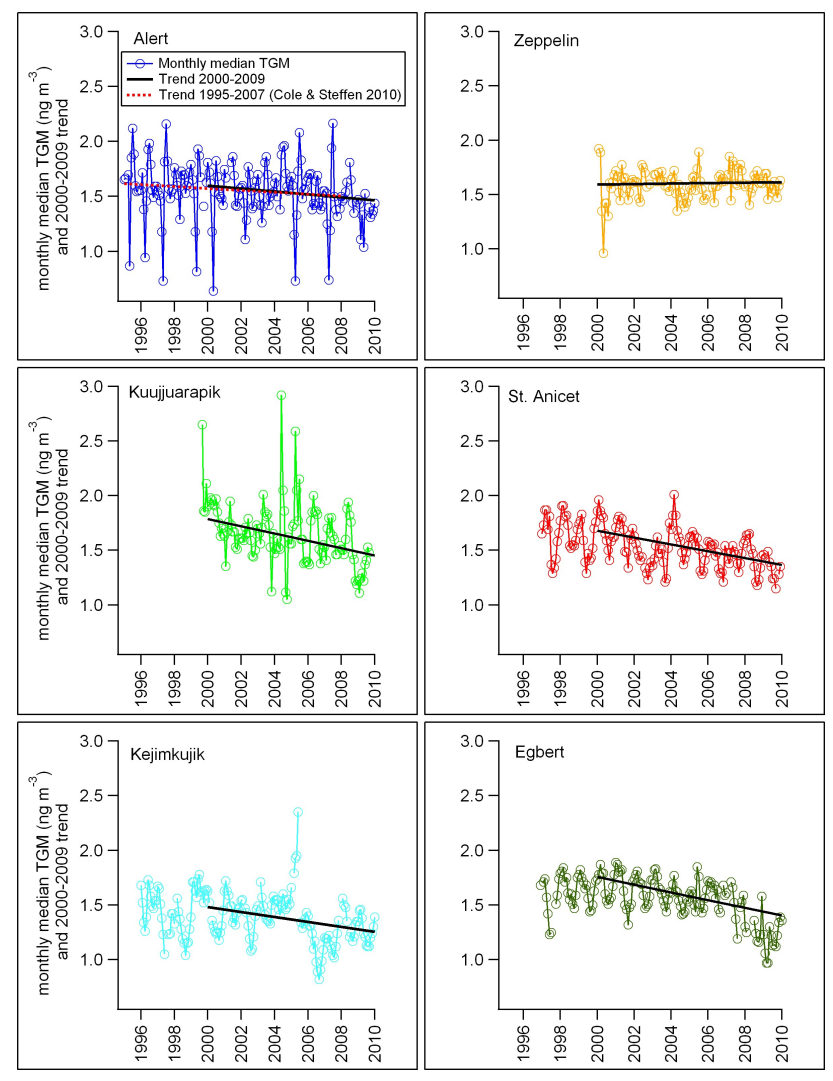

Fig. 4. Time series of monthly median TGM concentrations compared to time trends for 2000-2009 calculated from Sen's estimator of slope.

erating decline in global mercury air concentrations (Slemr et al., 2003, 2011).

The time series of TGM measurements for all sites are shown in Fig. 4 along with a line showing the time trend for 2000-2009 calculated using Sen's estimator of slope, with the centre of the line fixed to the median measured concentration for the decade (Table 2). In general, the time trends provide a reasonable fit to the time series, though some nonlinearity to the Egbert time series is noted. An abrupt decrease in TGM concentrations at Egbert at the beginning of 2008, which is not seen at St. Anicet or Kejimkujik, suggests a local source discontinuity and may explain why the trend at Egbert is the most negative (though not significantly different) of the three mid-latitude Canadian sites. High variability at Kuujjurapik is likely related to AMDEs during springtime and the impact of Hudson Bay on climate and gas exchange throughout the year. Figure 4 also includes the previouslyreported trend for Alert measurements from 1995 to 2007 (Cole and Steffen, 2010) for comparison. The trends are not significantly different. Finally, it is noted that the variability of TGM concentrations at Alert and Kuujjuarapik, occasional outliers at Zeppelin Station and Kejimkujik, and the 
non-linearity at Egbert result in the larger error bars for trend values at these sites (Fig. 3).

The trend results from the mid-latitude and sub-Arctic sites provide evidence of decreases in the global atmospheric mercury pool. Such a decrease is inconsistent with the most recent estimates of global anthropogenic mercury emissions that show increased emissions since 2000 (AMAP/Wilson et al., 2010; Streets et al., 2011; UNEP, 2013). These emission estimates include only anthropogenic releases, which comprise about a third of total mercury emissions to the atmosphere (Pirrone et al., 2010), and have estimated uncertainties on the order of $30 \%$. Recently, declining trends in oceanic mercury emissions in the North Atlantic have been shown to explain decreases in North Atlantic surface air concentrations (Soerensen et al., 2012). This trend in natural (or legacy) emissions may account for the decreasing levels of TGM at mid-latitude sites in the Northern Hemisphere. However, even if total global emissions decreased over 20002009, this alone does not explain the differences between Arctic and non-Arctic sites.

Compared to the lower latitude sites, seasonal TGM trends at Alert and Zeppelin Station are more variable from month to month, as shown in Fig. 2. From October through March, trends at Alert are not significantly different from the lower latitude sites. In contrast, trends in April, May and July at Alert are significantly higher than at any of the non-Arctic sites. At Zeppelin Station, the only significant decreasing trends are seen in January and February, with significant increases in concentration in May, August, September and October. August-October increases in TGM at Zeppelin occur at the time of minimum - and decreasing - Arctic Ocean ice cover, as will be discussed below. Alert and Zeppelin Station show similar seasonal trends from January to July but this agreement breaks down from August to December. Seasonality in the trends is also observed at Kuujjuarapik and Egbert. At Kuujjuarapik, the year-to-year decrease in TGM concentrations using data from November to May was faster than the decrease using data from June to October. This seasonality may be related to the influence of Hudson Bay on that site. During winter, the ice cover limits gas exchange between water and the atmosphere, and the Kuujjurapik site is likely influenced mainly by continental air masses, while in the ice-free season the site is influenced by GEM evasion from the Bay. Water bodies have been shown to be a net source of GEM to the atmosphere on both local and regional scales (Poissant and Casimir, 1998; Soerensen et al., 2010; Durnford et al., 2012). At Egbert, TGM concentrations in February and March declined most rapidly in comparison to the other months. This is likely due to unusually low values of TGM measured in 2008 and 2009 in those months, as seen in Fig. 4. Despite these seasonal variations, the overall trends at both Kuujjuarapik and Egbert are in good agreement with trends at mid-latitude sites.

The increasing trends at Alert and Zeppelin Station in some months and the more gradual (or no) decline in TGM concentrations overall suggest that mercury in Arctic air is experiencing different long-term changes on a regional basis. This difference is not entirely unexpected, given that the Arctic differs in its mercury chemistry as well as its climatology. In fact, springtime increases in TGM at Alert have previously been attributed to changes in the timing of the AMDE chemistry (Cole and Steffen, 2010). However, Kuujjuarapik also experiences AMDE chemistry and has not experienced the same springtime increases in TGM. Also, a trend in AMDE activity would likely affect Alert more than Zeppelin, since Alert experiences stronger and more frequent AMDEs, but the observed spring trends are similar at the two Arctic stations. The monthly TGM trends at Alert and Zeppelin Station also diverge from those at non-Arctic sites outside of the AMDE season, so this chemistry alone is insufficient to explain the trend differences. The impact on TGM concentration trends of mercury oxidation chemistry and other factors, such as changes in ocean flux and source regions for Arctic TGM compared to elsewhere, are discussed below.

GEM in the Arctic is subject to unique chemistry that leads to fast deposition to the surface in spring and emission from the snowpack and tundra in summer (Steffen et al., 2008). Therefore, changes in this chemistry would influence springtime trends in Arctic GEM levels (and TGM, assuming some RGM is lost to deposition or particulate scavenging). Specifically, decreased oxidation would effectively increase springtime GEM levels over the decade, in agreement with observed April and May TGM trends at Alert and Zeppelin Station. Since the springtime oxidation of GEM is linked to high levels of bromine radicals that also catalytically remove ozone from the boundary layer in spring (Simpson et al., 2007), a decline in these radicals should also lead to an increase in spring tropospheric ozone concentrations. Analysis of ozone measured at Alert from 2000 to 2009 (NAPS, 2013) revealed trends in March, April and May that were very similar to the trends in TGM with a decrease in March and increases in April and May, though only the May trend was significant (not shown). This agreement was not unexpected given the tight correlation between $\mathrm{TGM}$ and $\mathrm{O}_{3}$ in the polar spring (Schroeder et al., 1998) and supports the hypothesis of a contribution from bromine chemistry to the observed spring TGM trends.

Decreased oxidation of GEM would also result in decreases in RGM and/or TPM, the products of GEM oxidation. Speciated mercury has been measured at Alert since 2002, as shown in Fig. 5, to form one of the longest continuous data sets of speciated mercury. These data only cover the last eight years of the decade since automated techniques for measuring speciated mercury were developed quite recently (Landis et al., 2002). The results of a preliminary seasonal trend analysis on RGM, TPM and GEM are shown in Fig. 6. The results show significant increases in RGM in March, May and July, and increases in TPM in March, April and July. The March and April TPM trends and May RGM trend were large, representing $9-17 \% \mathrm{yr}^{-1}$ increases 


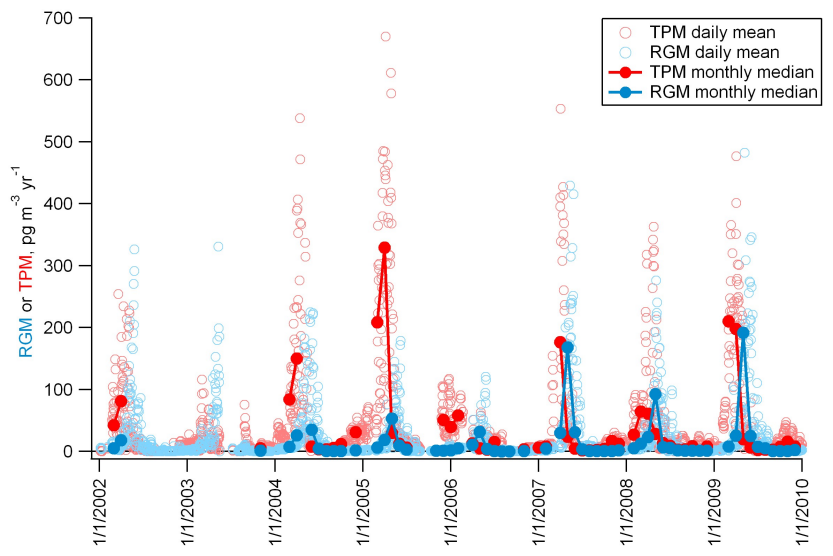

Fig. 5. Time series of reactive gaseous mercury (RGM) and particulate mercury (TPM) at Alert.

$\left(8-16 \mathrm{pg} \mathrm{m}^{-3} \mathrm{yr}^{-1}\right)$. Trends in March and July RGM and July TPM were small $\left(<1 \mathrm{pg} \mathrm{m}^{-3} \mathrm{yr}^{-1}\right)$ due to low concentrations of those species in those months. In all other months, either no significant trends were found or there were insufficient valid data to determine a trend. No significant decreases in TPM or RGM were found, suggesting that over this eight-year period GEM oxidation rates are unlikely to have decreased as we might expect from the longer-term TGM trends. In fact, decreases in GEM and increases in TPM and/or RGM in March and May suggest increased oxidation in the atmosphere. However, both GEM and TPM concentrations increased in April. Since TPM is the dominant oxidation product in April, a change in GEM oxidation would result in anti-correlated TPM and GEM trends, all other factors being equal. The importance of oxidation to the year-to-year variability in spring GEM concentrations is seen in Fig. 7, where monthly median GEM and the sum of oxidized mercury (RGM + TPM) are clearly anti-correlated in April. A comparison of GEM and RGM + TPM data in March and May, the two other dominant AMDE months, reveals similar relationships (not shown). However, other factors - such as deposition rates - must also influence the speciated mercury variability given that some years with similar April GEM concentrations (e.g. 2005 and 2007) had very different total oxidized mercury concentrations, leading to the observed positive trends in both GEM and TPM for 2002-2009. Note that monthly median values are shown in Fig. 7 for clarity; the trends shown in Fig. 6 were calculated using daily mean concentrations. The use of daily means reduces uncertainty (because of the larger sample size) and intrinsically weights years according to their relative data coverage.

The uncertainty in speciated mercury trends should not be understated even though the data has been subjected to rigorous QC procedures. The large interannual variability shown in Fig. 7 illustrates that longer data sets are needed in order to establish a robust long-term trend. This is also shown by the difference in the seasonal trend patterns for eight years

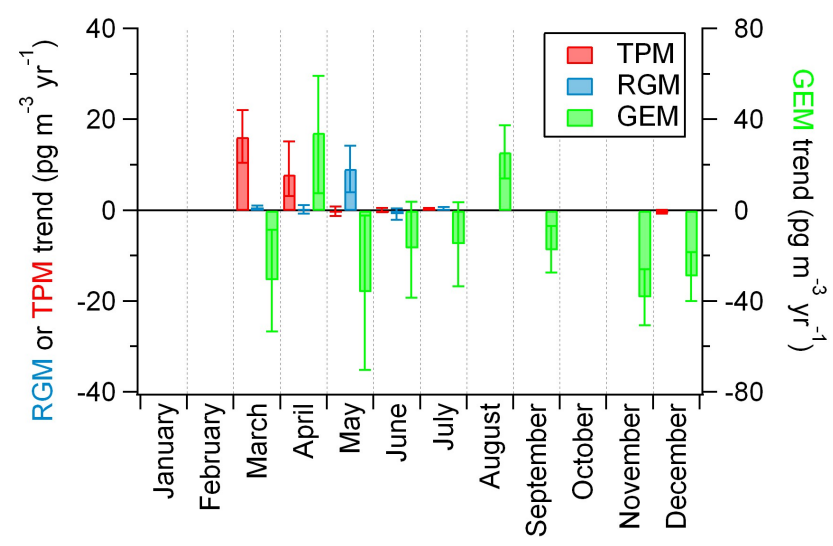

Fig. 6. Seasonal (monthly) trends in GEM, TPM and RGM from Alert based on daily average measurements, 2002-2009. Error bars represent $95 \%$ confidence limits.

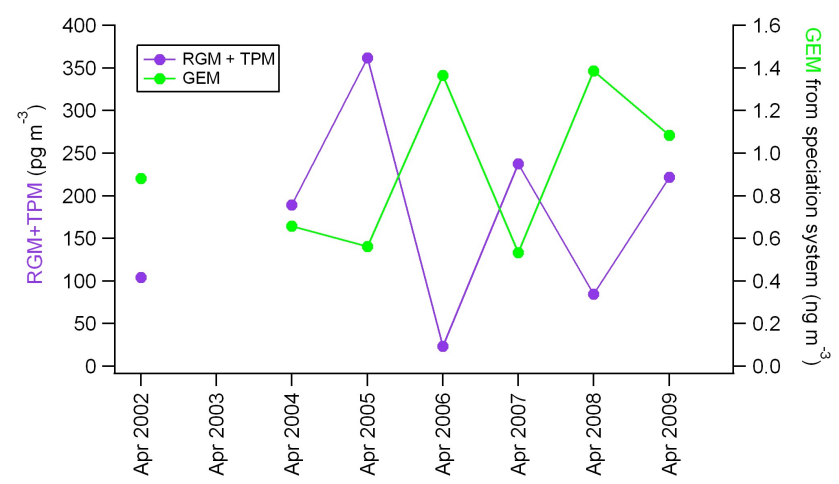

Fig. 7. Monthly median concentrations of GEM and the sum of RGM and TPM at Alert in the month of April. Only months with $>75 \%$ data coverage are included.

of GEM measurements (Fig. 6) and ten years of TGM measurements at Alert (Fig. 2). In addition, TPM trends are sensitive to any changes in particle size, e.g. due to changes in humidity or temperature, since only $\mathrm{PM}_{2.5}$ is collected. And the operational definition of the speciation measurements assumes there is no breakthrough of RGM, which cannot be tested until the exact chemical species that comprise RGM are identified. Given these uncertainties and the shorter data set, these speciation trends should be considered preliminary and not sufficient evidence to rule out decreased oxidation rates at Alert over 2000-2009, as is suggested by the springtime TGM trends at Alert, Zeppelin and Kuujjuarapik.

The seasonal trend differences between Arctic and lowerlatitude sites persist intermittently into the summer at Alert and the fall/winter at Zeppelin Station, indicating that spring AMDE chemistry cannot be the only reason for the latitudinal trend differences. Transport of mercury-laden air from source regions could increase mercury in Arctic air relative to mid-latitude regions in two ways. First, increased exchange of air between the Arctic and more polluted lower latitudes 
could be a positive driver of GEM trends (Macdonald et al., 2005). A recent dispersion modelling study found that from 1985 to 2008, the frequency of air arriving at Alert from the Arctic Ocean had decreased, and the frequency of transport from North America to Alert had increased (Hirdman et al., 2010). However, there was no significant transport trend at Zeppelin Station due to a slightly shorter time period (19902009). The interannual variability of this transport suggests that the 10-yr period discussed here for Alert would also be insufficient to discover this type of trend. In addition, their analysis of concentration trends in black carbon and sulphate found that transport changes accounted for only $0.3-7.2 \%$ of the observed pollutant trends at three Arctic stations, with emission changes being the dominant factor (Hirdman et al., 2010).

The second mechanism for a transport-driven difference between the Arctic and non-Arctic trends is a difference in source regions for the two areas. If the Arctic is more strongly impacted by emissions from Asia than the other sites, this could explain an increase or slower decrease in GEM concentrations given increasing Asian emissions over the decade (Streets et al., 2011). A source attribution study using Environment Canada's Global/Regional Atmospheric Heavy Metals (GRAHM) model found that Asia contributed about $30-35 \%$ of surface GEM at Arctic, sub-Arctic and mid-latitude sites, with relative contributions varying by site and season but no large difference between the Arctic and lower latitudes (Durnford et al., 2010). Even if we assume that Zeppelin Station (designated Ny-Alesund in Durnford et al., 2010) receives $35 \%$ of surface-level GEM from Asian sources and mid-latitude sites receive $30 \%$, in order to explain a difference in the trends of $2 \% \mathrm{yr}^{-1}$, emissions from Asia (natural and anthropogenic) would have to have increased by $26 \% \mathrm{yr}^{-1}$ and the rest of the global emissions decreased by $14 \% \mathrm{yr}^{-1}$ for the decade, which is a much larger change than can be explained by current inventories (AMAP/Wilson et al., 2010; UNEP, 2013). Therefore we conclude that some of the difference in trends may be explained by a difference in source regions, but not the majority. Similarly, North American emissions have a relatively greater impact at mid-latitude sites, as evidenced by a potential source contribution function (PSCF) study done at St. Anicet (Poissant, 1999), but according to the global model they contributed only $10-20 \%$ of the total mercury observed at all sites: about $0.15 \mathrm{ng} \mathrm{m}^{-3}$ at the two Arctic sites and about $0.3-0.4 \mathrm{ng} \mathrm{m}^{-3}$ at the non-Arctic sites (Durnford et al., 2010). Based on the observed trends (Table 2), if emissions from all other regions stayed constant, a decrease of about $8-10 \% \mathrm{yr}^{-1}$ in North American emissions (anthropogenic and natural) would be needed to account for the trends at Alert and mid-latitude sites over the ten years, and would not be consistent with the observed Zeppelin Station trend. However, anthropogenic emissions from North America did not dramatically decrease after 2000 (AMAP/Wilson et al., 2010; Streets et al., 2011). For example, Canadian emissions estimates (not including natural sources or biomass burning) show a decrease of only about $2 \% \mathrm{yr}^{-1}$ over the decade (NPRI, 2012). It is possible that natural emissions have decreased, but at this point we have no basis for invoking a large decrease in natural emissions from North America that does not extend to the Arctic. Therefore we conclude that North American emission trends may also close some of the gap between mid-latitude and Arctic TGM trends but are unlikely to account for all of the decrease in TGM at the mid-latitude sites.

Another factor influencing GEM trends in the Arctic could be evasion of GEM from the ocean to the atmosphere. Declining North Atlantic mercury concentrations could explain decreasing GEM levels at mid-latitude sites (Soerensen et al., 2012), but since sea ice may form a physical barrier to evasion (Andersson et al., 2008), decreases in Arctic sea ice cover that occurred over the decade (Fetterer et al., 2002, updated 2009) could result in enhanced evasion and help explain the more positive TGM trends in the Arctic. Analogously, decreased ice cover and warmer temperatures in the Arctic since 1993 have been found to be positive forcers of air concentrations of organic pollutants (Ma et al., 2011). In support of this hypothesis for mercury, the Arctic Ocean was identified as a likely source of mercury to the Arctic atmosphere in summer (Hirdman et al., 2009; Durnford et al., 2012), and the bulk of air arriving at both Alert and Zeppelin stations arrives from the Arctic Ocean (Hirdman et al., 2010). In addition, some of the mercury in surface ocean water may come from riverine input as melt water flushes terrestrial mercury out to sea (Andersson et al., 2008; Fisher et al., 2012). It has been postulated that a warming climate could increase the amount of mercury released to Arctic rivers as mercury locked in permafrost is released (Schuster et al., 2011). This would make more mercury available in the surface Arctic Ocean for subsequent reduction and emission to the atmosphere. A positive trend in Arctic Ocean emissions by either mechanism would help explain the TGM trends in the Arctic in the summer but also throughout much of the year, since sea ice is declining in all months (Fetterer et al., 2002, updated 2009) and simulations predict some evasion from the ocean as a whole in all months other than January and December (Fisher et al., 2012). Sea ice cover, and changes in that cover, are also spatially variable and may therefore explain differences in the TGM trends between Alert and Zeppelin Station. For example, Alert is usually surrounded by multi-year ice throughout year, often including the summer, while the island of Spitsbergen, where Zeppelin Station is located, is normally surrounded by open water in the summer and fall and occasionally the western coast is free of ice year-round. Therefore, oceanic emissions may act as a significant local source to Zeppelin Station but a more regional, diffuse source at Alert. 


\section{Conclusions}

This trend analysis provides the first evidence that mercury in the high Arctic atmosphere behaves differently than at midlatitudes not only on short time scales (e.g. AMDE chemistry) but also in long-term trends. We have postulated several mechanisms to explain this difference (AMDE chemistry, sea ice behavior, transport patterns) and provided a first look at trends in speciated mercury compounds at Alert. It is important to determine the mechanism responsible for the more positive TGM trends at Arctic sites, because the effect on the deposition of mercury to the Arctic ecosystem could be very different. For example, decreased oxidation chemistry would lead to increased spring TGM concentrations but decreased deposition to the surface, while increased transport of mercury from lower latitudes would have a positive effect on both Arctic TGM concentrations and total mercury deposition. Detailed modeling studies and better knowledge of natural emission trends would help resolve the reason(s) for latitude-dependent trends and also extrapolate the impact on mercury deposition in the Arctic. Also, continued observations in the Antarctic (Pfaffhuber et al., 2012), where AMDEs occur but emission sources are more distant, and at other remote Northern Hemisphere locations that do not experience AMDEs, may help separate the effects of chemistry, emissions, and transport. Finally, we note that the high variability of atmospheric mercury concentrations in the Arctic - particularly in the spring and summer - indicates that continued monitoring is required in order to be confident in the long-term trends at these locations.

Acknowledgements. The authors would like to thank numerous site personnel for their valuable contributions as well as Julie Narayan for data processing. Funding and support for this project was provided by the Northern Contaminant Program, Environment Canada, the Government of Canada program for International Polar Year, the Norwegian Climate and Pollution Agency, the Norwegian Polar Institute, Centre d'études nordiques (Université Laval), and the Arctic Monitoring and Assessment Program. Measurements of TGM at the five Canadian sites were performed under Environment Canada's Canadian Atmospheric Mercury Network (CAMNet) and/or Canadian Air and Precipitation Monitoring Network (CAPMoN) and are publicly available via the National Atmospheric Chemistry Database (NAtChem) website: http://www.ec.gc.ca/natchem/. KAP and TB are grateful for the technical support offered by the staff at the Norwegian Polar Institute and want to thank their excellent instrument caretaker Jan H. Wasseng.

Edited by: A. Dastoor

\section{References}

AMAP: Arctic Monitoring and Assessment Programme (AMAP) Assessment 2002: Heavy Metals in the Arctic, Oslo, Norway, 265 pp., 2005.

AMAP: AMAP Assessment 2011: Mercury in the Arctic, Arctic Monitoring and Assessment Programme (AMAP), Oslo, Norwayxiv, 193 pp., 2011.

AMAP/UNEP: Technical Background Report to the Global Atmospheric Mercury Assessment, Arctic Monitoring and Assessment Programme/UNEP Chemicals Branch, 159 pp., 2008.

AMAP/Wilson, S., Munthe, J., Sundseth, K., Kindbom, K., Maxson, P., Pacyna, J., and Steenhuisen, F.: Updating historical global inventories of anthropogenic mercury emissions to air, AMAP Technical Report No. 3 (2010), Arctic Monitoring and Assessment Programme, Oslo, Norway, 2010.

Andersson, M. E., Sommar, J., Gårdfeldt, K., and Lindqvist, O.: Enhanced concentrations of dissolved gaseous mercury in the surface waters of the Arctic Ocean, Mar. Chem., 110, 190-194, 2008.

Aspmo, K., Gauchard, P.-A., Steffen, A., Temme, C., Berg, T., Bahlmann, E., Banic, C., Dommergue, A., Ebinghaus, R., Ferrari, C., Pirrone, N., Sprovieri, F., and Wibetoe, G.: Measurements of atmospheric mercury species during an international study of mercury depletion events at Ny-Alesund, Svalbard, spring 2003. How reproducible are our present methods?, Atmos. Environ., 39, 7607-7619, 2005.

Berg, T., Sekkesæter, S., Steinnes, E., Valdal, A. K., and Wibetoe, G.: Springtime depletion of mercury in the European Arctic as observed at Svalbard, Sci. Total Environ., 304, 43-51, 2003.

Cole, A. S. and Steffen, A.: Trends in long-term gaseous mercury observations in the Arctic and effects of temperature and other atmospheric conditions, Atmos. Chem. Phys., 10, 4661-4672, doi:10.5194/acp-10-4661-2010, 2010.

Dietz, R., Outridge, P. M., and Hobson, K. A.: Anthropogenic contributions to mercury levels in present-day Arctic animals - A review, Sci. Total Environ., 407, 6120-6131, 2009.

Durnford, D., Dastoor, A., Figueras-Nieto, D., and Ryjkov, A.: Long range transport of mercury to the Arctic and across Canada, Atmos. Chem. Phys., 10, 6063-6086, doi:10.5194/acp-10-60632010, 2010.

Durnford, D., Dastoor, A., Ryzhkov, A., Poissant, L., Pilote, M., and Figueras-Nieto, D.: How relevant is the deposition of mercury onto snowpacks? - Part 2: A modeling study, Atmos. Chem. Phys., 12, 9251-9274, doi:10.5194/acp-12-9251-2012, 2012.

Ebinghaus, R., Jennings, S. G., Schroeder, W. H., Berg, T., Donaghy, T., Ferrara, R., Guentzel, J., Kenny, D., Kock, H. H., Kvietkus, K., Landing, W., Mazzolai, B., Mühleck, Munthe, J., Prestbo, E. M., Schneeberger, D., F., S., Sommar, J., Urba, A., Wallschläger, D., and Xiao, Z.: International field intercomparison measurements of atmospheric mercury species at Mace Head, Ireland, Atmos. Environ., 33, 3063-3073, 1999.

Ebinghaus, R., Jennings, S. G., Kock, H. H., Derwant, R. G., Manning, A. J., and Spain, T. G.: Decreasing trends in total gaseous mercury in baseline air at Mace Head, Ireland from 1996-2009, Atmos. Environ., 159, 1577-1583, 2011.

Fetterer, F., Knowles, K., Meier, W., and Savoie, M.: Sea Ice Index, http://nsidc.org/data/seaice_index/ (last access: 2012), National Snow and Ice Data Center, Boulder, CO, 2002, updated 2009. 
Fisher, J. A., Jacob, D. J., Soerensen, A. L., Amos, H. M., Steffen, A., and Sunderland, E. M.: Riverine source of Arctic Ocean mercury inferred from atmospheric observations, Nature Geosci., 5, 499-504, doi:10.1038/ngeo1478, 2012.

Gilbert, R. O.: Statistical Methods for Environmental Pollution Monitoring, Van Nostrand Reinhold Company, New York, 204240, 1987.

Hirdman, D., Aspmo, K., Burkhart, J. F., Eckhardt, S., Sodemann, H., and Stohl, A.: Transport of mercury in the Arctic atmosphere: Evidence for a springtime net sink and summer-time source, Geophys. Res. Lett., 36, L12814, doi:10.1029/2009g1038345, 2009.

Hirdman, D., Burkhart, J. F., Sodemann, H., Eckhardt, S., Jefferson, A., Quinn, P. K., Sharma, S., Ström, J., and Stohl, A.: Longterm trends of black carbon and sulphate aerosol in the Arctic: changes in atmospheric transport and source region emissions, Atmos. Chem. Phys., 10, 9351-9368, doi:10.5194/acp-10-93512010, 2010.

Holmes, C. D., Jacob, D. J., Corbitt, E. S., Mao, J., Yang, X., Talbot, R., and Slemr, F.: Global atmospheric model for mercury including oxidation by bromine atoms, Atmos. Chem. Phys., 10, 12037-12057, doi:10.5194/acp-10-12037-2010, 2010.

Kellerhals, M., Beauchamp, S., Belzer, W., Blanchard, P., Froude, F., Harvey, B., McDonald, K., Pilote, M., Poissant, L., Puckett, K., Schroeder, W. H., Steffen, A., and Tordon, R.: Temporal and spatial variability of total gaseous mercury in Canada: Results from the Canadian Atmospheric Mercury Measurement Network (CAMNet), Atmos. Environ., 37, 1003-1011, 2003.

Landis, M., Stevens, R. K., Schaedlich, F., and Prestbo, E. M.: Development and characterization of an annular denuder methodology for the measurement of divalent inorganic reactive gaseous mercury in ambient air, Environ. Sci. Technol., 36, 3000-3009, 2002.

Lindberg, S. E., Brooks, S., Lin, C.-J., Scott, K. J., Landis, M. S., Stevens, R. K., Goodsite, M., and Richter, A.: Dynamic oxidation of gaseous mercury in the Arctic troposphere at polar sunrise, Environ. Sci. Technol., 36, 1245-1256, 2002.

Ma, J., Hung, H., Tian, C., and Kallenborn, R.: Revolatilization of persistent organic pollutants in the Arctic induced by climate change, Nature Clim. Change, 1, 255-260, 2011.

Macdonald, R. W., Harner, T., and Fyfe, J.: Recent climate change in the Arctic and its impact on contaminant pathways and interpretation of temporal trend data, Sci. Total Environ., 342, 5-86, 2005.

McMillan, A. C., MacIver, D., and Sukloff, W. B.: Atmospheric environmental information - an overview with Canadian examples, Environ. Modell. Softw., 15, 245-248, 2000.

Muir, D. C. G., Wang, X., Yang, F., Nguyen, N., Jackson, T. A., Evans, M. S., Douglas, M., Kock, G., Lamoureaux, S., Pienitz, R., Smol, J. P., Vincent, W. F., and Dastoor, A.: Spatial trends and historical deposition of mercury in eastern and northern Canada inferred from lake sediment cores, Environ. Sci. Technol., 43, 4802-4809, 2009.

Munthe, J., Wangberg, I., Pirrone, N., Iverfeldt, A., Ferrara, R., Ebinghaus, R., Feng, X., Gardfeldt, K., Keeler, G., Lanzillotta, E., Liundberg, S. E., Lu, J., Mamane, Y., Prestbo, E., Schmolke, S., Schroeder, W. H., Sommar, J., Sprovieri, F., Stevens, R. K., Stratton, W., Tuncel, G., and Urba, A.: Intercomparison of methods for sampling and analysis of atmospheric mercury species,
Atmos. Environ., 35, 3007-3017, 2001.

NAPS: National Air Pollution Surveillance Network, http:// www.etc-cte.ec.gc.ca/napsdata/Default.aspx, last access: January 2013.

NPRI: Heavy Metals and Persistent Organic Pollutants (National: 1990-2010), http://www.ec.gc.ca/inrp-npri/default.asp? lang=en $\backslash \& n=0 E C 58 C 98-$, last access: June 2012.

Outridge, P. M., Macdonald, R. W., Wang, F., Stern, G. A., and Dastoor, A. P.: A mass balance inventory of mercury in the Arctic Ocean, Environ. Chem., 5, 89-111, doi:10.1071/en08002, 2008.

Pacyna, E. G., Pacyna, J. M., Steenhuisen, F., and Wilson, S.: Global anthropogenic mercury emission inventory for 2000, Atmos. Environ., 40, 4048-4063, 2006.

Pfaffhuber, K. A., Berg, T., Hirdman, D., and Stohl, A.: Atmospheric mercury observations from Antarctica: seasonal variation and source and sink region calculations, Atmos. Chem. Phys., 12, 3241-3251, doi:10.5194/acp-12-3241-2012, 2012.

Pirrone, N., Cinnirella, S., Feng, X., Finkelman, R. B., Friedli, H. R., Leaner, J., Mason, R., Mukherjee, A. B., Stracher, G. B., Streets, D. G., and Telmer, K.: Global mercury emissions to the atmosphere from anthropogenic and natural sources, Atmos. Chem. Phys., 10, 5951-5964, doi:10.5194/acp-10-59512010, 2010.

Poissant, L.: Field observation of total gaseous mercury behaviour: Interactions with ozone concentration and water vapour mixing ratio in air at a rural site, Water Air Soil Pollut., 97, 341-353, 1997.

Poissant, L.: Potential sources of atmospheric total gaseous mercury in the St. Lawrence River valley, Atmos. Environ., 33, 2537 2547, 1999.

Poissant, L.: Total gaseous mercury in Quebec (Canada) in 1998, Sci. Total Environ., 259, 191-201, 2000.

Poissant, L. and Casimir, A.: Water-air and soil-air exchange rate of total gaseous mercury measured at background sites, Atmos. Environ., 32, 883-893, 1998.

Poissant, L. and Pilote, M.: Time series analysis of atmospheric mercury in Kuujjuarapik/Whapmagoostui (Quebec), Journal de Physique IV, 107, 1079-1082, 2003.

Schroeder, W. H. and Munthe, J.: Atmospheric mercury - An overview, Atmos. Environ., 32, 809-822, 1998.

Schroeder, W. H., Anlauf, K. G., Barrie, L. A., Lu, J. Y., Steffen, A., Schneeberger, D. R., and Berg, T.: Arctic springtime depletion of mercury, Nature, 394, 331-332, 1998.

Schuster, P. F., Striegl, R. G., Aiken, G. R., Krabbenhoft, D. P., Dewild, J. F., Butler, K., Kamark, B., and Dornblaser, M.: Mercury export from the Yukon River basin and potential response to a changing climate, Environ. Sci. Technol., 45, 9262-9267, 2011.

Selin, N. E.: Global biogeochemical cycling of mercury: A review, Annual Review of Environment and Resources, 34, 43-63, 2009.

Simpson, W. R., von Glasow, R., Riedel, K., Anderson, P., Ariya, P., Bottenheim, J., Burrows, J., Carpenter, L. J., Frieß, U., Goodsite, M. E., Heard, D., Hutterli, M., Jacobi, H.-W., Kaleschke, L., Neff, B., Plane, J., Platt, U., Richter, A., Roscoe, H., Sander, R., Shepson, P., Sodeau, J., Steffen, A., Wagner, T., and Wolff, E.: Halogens and their role in polar boundary-layer ozone depletion, Atmos. Chem. Phys., 7, 4375-4418, doi:10.5194/acp-74375-2007, 2007. 
Slemr, F., Brunke, E., Ebinghaus, R., Temme, C., Munthe, J., Wängberg, I., Schroeder, W. H., Steffen, A., and Berg, T.: Worldwide trend of atmospheric mercury since 1977, Geophys. Res. Lett., 30, 23-21, 2003.

Slemr, F., Ebinghaus, R., Brenninkmeijer, C. A. M., Hermann, M., Kock, H. H., Martinsson, B. G., Schuck, T., Sprung, D., van Velthoven, P., Zahn, A., and Ziereis, H.: Gaseous mercury distribution in the upper troposphere and lower stratosphere observed onboard the CARIBIC passenger aircraft, Atmos. Chem. Phys., 9, 1957-1969, doi:10.5194/acp-9-1957-2009, 2009.

Slemr, F., Brunke, E.-G., Ebinghaus, R., and Kuss, J.: Worldwide trend of atmospheric mercury since 1995, Atmos. Chem. Phys., 11, 4779-4787, doi:10.5194/acp-11-4779-2011, 2011.

Soerensen, A. L., Sunderland, E. M., Holmes, C. D., Jacob, D. J., Yantosca, R. M., Skov, H., Christensen, J. H., Strode, S. A., and Mason, R. P.: An improved global model for air-sea exchange of mercury: High concentrations over the North Atlantic, Environ. Sci. Technol., 44, 8574-8580, 2010.

Soerensen, A. L., Jacob, D. J., Streets, D. G., Witt, M. L. I., Ebinghaus, R., Mason, R. P., Andersson, M., and Sunderland, E. M.: Multi-decadal decline of mercury in the North Atlantic atmosphere explained by changing subsurface seawater concentrations, Geophys. Res. Lett., 39, L21810, doi:10.1029/2012GL053736, 2012.

Sprovieri, F., Pirrone, N., Ebinghaus, R., Kock, H., and Dommergue, A.: A review of worldwide atmospheric mercury measurements, Atmos. Chem. Phys., 10, 8245-8265, doi:10.5194/acp10-8245-2010, 2010.

Steffen, A. and Schroeder, W.: Standard Operating Procedures Manual for Total Gaseous Mercury Measurements Toronto, 1999.

Steffen, A., Schroeder, W., Bottenheim, J., Narayan, J., and Fuentes, J.: Atmospheric mercury concentrations: measurements and profiles near snow and ice surfaces in the Canadian Arctic during Alert 2000, Atmos. Environ., 36, 2653-2661, 2002.

Steffen, A., Douglas, T., Amyot, M., Ariya, P., Aspmo, K., Berg, T., Bottenheim, J., Brooks, S., Cobbett, F., Dastoor, A., Dommergue, A., Ebinghaus, R., Ferrari, C., Gardfeldt, K., Goodsite, M. E., Lean, D., Poulain, A. J., Scherz, C., Skov, H., Sommar, J., and Temme, C.: A synthesis of atmospheric mercury depletion event chemistry in the atmosphere and snow, Atmos. Chem. Phys., 8, 1445-1482, doi:10.5194/acp-8-1445-2008, 2008.
Steffen, A., Scherz, T., Olson, M. L., Gay, D. A., and Blanchard, P.: A comparison of data quality control protocols for atmospheric mercury speciation measurements, J. Environ. Monit., 14, 752765, doi:10.1039/c2em10735j, 2012.

Streets, D. G., Devane, M. K., Lu, Z., Sunderland, E. M., and Jacob, D. J.: All-time releases of mercury to the atmosphere from human activities, Environ. Sci. Technol., 45, 10485-10491, doi:10.1021/es202765m, 2011.

Swartzendruber, P. C., Chand, D., Jaffe, D. A., Smith, J., Reidmiller, D., Gratz, L., Keeler, J., Strode, S., Jaegle, L., and Talbot, R.: Vertical distribution of mercury, CO, ozone, and aerosol scattering coefficient in the Pacific Northwest during the spring 2006 INTEX-B campaign, J. Geophys. Res.-Atmos., 113, D10305, doi:10.1029/2007JD009579, 2008.

Tait, E., Steffen, A., and Blanchard, P.: Canadian Atmospheric Mercury Network (CAMNet) Audit Report October to December 1999, Environment Canada, Toronto, Canada, 2000.

Temme, C., Einax, J. W., Ebinghaus, R., and Schroeder, W. H.: Measurements of Atmospheric Mercury Species at a Coastal Site in the Antarctic and over the South Atlantic Ocean during Polar Summer, Environ. Sci. Technol., 37, 22-31, 2003.

Temme, C., Blanchard, P., Steffen, A., Beauchamp, S. T., Poissant, L., Tordon, R. J., and Weins, B.: Trend, seasonal and multivariate analysis study of total gaseous mercury data from the Canadian Atmospheric Mercury Measurement Network (CAMNet), Atmos. Environ., 41, 5423-5441, 2007.

UNEP: Global Mercury Assessment 2013: Sources, Emissions, Releases and Environmental Transport, UNEP Chemicals Branch, Geneva, 2013.

van Belle, G. and Hughes, J. P.: Nonparametric tests for trend in water quality, Water Resour. Res., 20, 127-136, 1984. 